\title{
MEDIA PEMBELAJARAN DAN PERAN PENTINGNYA DALAM PENGAJARAN DAN PEMBELAJARAN BAHASA ARAB
}

\author{
Asni Furoidah \\ IAI Al-Falah As-Sunniyyah Kencong Jember \\ (asnifuroidah148@gmail.com)
}

\begin{abstract}
Learning media plays an important role in learning Arabic. Learning media is not only good for children's students, but also for adult students. The learning media used to convey the contents of teaching materials consisting of books, tape recorders, tapes, video cameras, video recorders, films, photos, pictures, graphics, television and computers are components of learning resources that contain teaching materials that can stimulate a person to learn. . The use of audio media in Arabic learning is very important in the material الاستماع, the teacher who delivers material using audio media will make it easier for students to hear every vocabulary that is pronounced correctly. The use of visual media can increase students <interest in writing (الأنشاء) by relying on students imaginations. Furthermore, through audio-visual media, students can get new experiences that directly touch the motivation to learn Arabic, audiovisual media in Arabic is also known as al-wasail al-samsiyyah wa al-basariyyah (وسائل السمعية والبصرية). This type of research is library research (Library Research). This research is qualitative in nature because the object of research is in the form of learning media which is explained with descriptions of words so that it can be understood easily. Learning media are used in order to improve or enhance the quality of the teaching and learning process. With this media, it is hoped that the learning atmosphere will not be boring and become more interesting so that it can foster student interest in learning Arabic lessons and more importantly the achievement of the objectives of teaching and learning activities and the curriculum.
\end{abstract}

Keywords: Learning Media, Arabic, Role. 


\begin{abstract}
Abstrak
Media pembelajaran memegang peranan penting dalam pembelajaran bahasa Arab. Media pembelajaran tidak hanya baik untuk peserta didik anak-anak, tetapi juga untuk peserta didik dewasa. Media pembelajaran yang digunakan untuk menyampaikan isi bahan ajar yang terdiri dari buku, tape recorder, tape, kamera video, perekam video, film, foto, gambar, grafik, televisi dan komputer merupakan komponen sumber belajar yang berisi bahan ajar yang dapat merangsang seseorang untuk belajar. Penggunaan media audio dalam pembelajaran bahasa Arab sangat penting dalam materi الاستماع, guru yang menyampaikan materi dengan menggunakan media audio akan memudahkan siswa dalam mendengar setiap kosakata yang diucapkan dengan benar. Penggunaan media visual dapat meningkatkan minat siswa dalam menulis (الأنشاء) dengan mengandalkan imajinasi siswa. Selanjutnya melalui media audio visual, siswa dapat memperoleh pengalaman baru yang secara langsung menyentuh motivasi belajar bahasa Arab, media audiovisual dalam bahasa Arab disebut juga dengan al-wasail al-sam>iyyah wa al-basariyyah (وسائل) (السمعية والبصرية. Jenis penelitian ini adalah penelitian perpustakaan (Library Research). Penelitian ini bercorak kualitatif karena obyek penelitian berupa media pembelajaran yang dijelaskan dengan deskripsi kata-kata sehingga dapat dipahami dengan mudah. Media pembelajaran digunakan dalam rangka upaya peningkatan atau mempertinggi mutu proses kegiatan belajar mengajar. Dengan media ini, diharapkan suasanana pembelajaran tidak membosankan dan menjadi lebih menarik sehingga bisa menumbuhkan minat siswa untuk belajar pelajaran bahasa Arab dan yang lebih penting adalah tercapainya tujuan kegiatan belajar mengajar dan kurikulum.
\end{abstract}

Kata Kunci: Media Pembelajaran, Bahasa Arab, Peran.

\title{
Pendahuluan
}

Media pembelajaran merupakan alat bantu untuk mencapai tujuan pembelajaran itu sendiri juga media merupakan suatu kenyataan yang tidak dapat dipungkiri. ${ }^{1}$ Oleh karena itu, guru dituntut mampu menggunakan alat-alat yang digunakan oleh sekolah dan tidak tertutup kemungkinan bahwa alat-alat tersebut sesuai dengan perkembangan zaman. Guru sekurang-kurangnya dapat menggunakan alat yang efektif dan efisien dalam upaya mencapai tujuan pengajaran yang diharapkan. Media pembelajaran dapat berfungsi sebagai stimulus terhadap pikiran, pesan, perhatian dan minat siswa dalam memperjelas materi pelajaran karena apabila dengan menggunakan penjelasan verbal saja siswa akan melupakannya. Media pembelajaran merupakan salah satu unsur yang amat penting dalam proses belajar

${ }^{1}$ Khalilullah, Media Pembelajaran Bahasa Arab, (Yogyakarta: Aswaja Pressindo, 2012), 1-2 
mengajar, selain itu media pembelajaran juga merupakan salah satu cara untuk memotivasi dan berkomunikasi dengan siswa agar lebih efektif.

Bahasa Arab sebagai bahasa asing (Foreign Language) kehadirannya cukup penting bagi masyarakat Indonesia. Sejarah panjang telah mengukir bagaimana pertumbuhan dan perkembangan bahasa Arab di Indonesia walaupun fungsi yang diemban terbatas pada bahasa peribaratan yang digunakan dalam ritual sehari-hari seperti sholat, pada tingkat pendidikan atau di sekolah, bahasa Arab diajarkan pada madrasah setingkat pendidikan dasar hingga perguruan tinggi Islam. Sayangnya, terkadang output yang dihasilkan tidak sebanding dengan standar kompetensi kemampuan siswa yang diharapkan oleh pemerintah. ${ }^{2}$

Pengajaran adalah suatu aktivitas (proses) mengajar-belajar. Di dalamnya ada dua subjek yaitu guru dan peserta didik. Tugas dan tanggung jawab utama seorang guru adalah mengelola pengajaran dengan lebih efektif, dinamis, efisien dan positif yang ditandai dengan adanya kesadaran dan keterlibatan aktif diantara dua subjek pengajaran. Guru sebagai penginisiatif awal dan pengarah serta pembimbing, sedang peserta didik sebagai yang mengalami dan terlibat aktif untuk memperoleh perubahan diri dalam pengajaran. Untuk itu, diperlukan pengelolaan pengajaran yang baik. Pengelolaan pembelajaran yang baik harus dikembangkan berdasarkan pada prinsip-prinsip pengajaran. ${ }^{3}$

Dalam proses pembelajaran, media adalah merupakan alat bantu untuk mencapai tujuan pembelajaran itu sendiri, juga media merupakan suatu kenyataan yang tidak dapat dipungkiri. Oleh karena itu, guru dituntut mampu menggunakan alatalat yang digunakan oleh sekolah dan tidak menutup kemungkinan bahwa alatalat tersebut sesuai dengan perkembangan zaman. Guru sekurang-kurangnya dapat menggunakan alat yang murah dan efisien dalam upaya mencapai tujuan pengajaran yang diharapkan.

Dari sini dapat diketahui bahwa penggunaan media pembelajaran merupakan salah satu upaya guru dalam meningkatkan motivasi belajar siswa, karena adakalanya guru ketika proses belajar mengajar menghadapi siswa yang malas, bosan,

${ }^{2}$ Alvia Putri Prima Sari, Tinjauan Terhadap Metode Pembelajaran Bahasa Arab: Metode Qawaid \& Terjemah, Metode Langsung, Metode Audiolingual Dan Metode Gabungan, Jurnal Tarbiyatuna Volume 3 Nomor 2 (Desember 2018), 104

${ }^{3}$ Ahmad Rohani, Pengelolaan Pengajaran, (Jakarta: PT Rineka Cipta, 2004), 1 
jenuh dan lain sebagainya. Apabila keadaan seperti ini dibiarkan akan berakibat pada motivasi belajar siswa menurun dan untuk mengatasinya diperlukan suatu dorongan dan rangsangan agar siswa memiliki kemauan untuk belajar.

\section{Metode Penelitian}

Jenis penelitian ini adalah penelitian perpustakaan (Library Research). Penelitian ini bercorak kualitatif karena obyek penelitian berupa media pembelajaran yang dijelaskan dengan deskripsi kata-kata sehingga dapat dipahami dengan mudah. ${ }^{4}$

Dalam penelitian ini, media pembelajaran sebagai sarana terpenting dalam proses pengajaran dan pembelajaran sehingga menjadi penting untuk diterapkan dalam mata pelajaran Bahasa Arab. Diantaranya adalah jenis-jenis media pembelajaran Bahasa Arab yang disesuaikan dengan kebutuhan peserta didik nantinya.

\section{Pengertian Media Pembelajaran}

Kata media berasal dari bahasa latin yang adalah bentuk jamak dari medium batasan mengenai pengertian media sangat luas, namun kita membatasi pada media pendidikan saja yakni media yang digunakan sebagai alat dan bahan kegiatan pembelajaran. Kata media merupakan bentuk jamak dari kata medium. Medium dapat didefinisikan sebagai perantara atau pengantar terjadinya komunikasi dari pengirim menuju penerima. Media merupakan salah satu komponen komunikasi yaitu sebagai pembawa pesan dari komunikator menuju komunikan. Berdasarkan definisi tersebut dapat dikatakan bahwa proses pembelajaran merupakan proses komunikasi. ${ }^{5}$

Dalam bahasa Arab, media adalah wasail yang berarti perantara atau pengantar pesan dari pengirim kepada penerima pesan. Menurut Abdul Alim Ibrahim media adalah "الوسائل التوضيحية (sarana untuk memperjelas)". ${ }^{6}$ Ada beberapa istilah yang digunakan dalam media diantaranya adalah al-Wasa'il al-Idhah atau al-Wasa'il al-Taudhihiyyah, Wasa'il al-Ta'lim, al-Wasa'il al-Ta'limiyah dan ada juga yang menggunakan istilah al-Mu'ayyanaat al-Sam'iyah wa al-Bashariyah. Meskipun istilah yang digunakan berbeda, tetapi kesemuanya mengarah kepada pengertian yang sama, yaitu media pembelajaran yang dalam sejarahnya pertama kali disebut

${ }^{4}$ Hadari Nawawi, Metodologi Penelitian Bidang Sosial, (Yogyakarta: Gadjahmada University Press, 1995), 79

${ }^{5}$ Daryanto, Media Pembelajaran, (Yogyakarta: Gava Media, 2010), 4

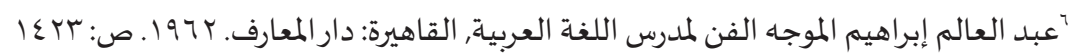


visual education (alat peraga pandang) kemudian berubah lagi menjadi audio visual aids (bahan pengajaran), berubah lagi menjadi audio visual communication (komunikasi pandang dengar) dan terakhir menjadi educational technology (teknologi pendidikan atau teknologi pembelajaran) ${ }^{7}$

Menurut NEA (National Educational Assosiation), media adalah bentuk-bentuk komunikasi baik tercetak maupun audio visual serta peralatannya. Media hendaknya dapat dimanipulasi, dapat dilihat, dapat didengar dan dibaca atau dibicarakan beserta instrumen yang dipergunakan dengan baik dalam kegiatan belajar mengajar serta dapat mempengaruhi efektifitas program instruksional. ${ }^{8}$

Menurut Amir Achsin media adalah setiap orang, bahan, alat atau kejadian yang memantapkan kondisi memungkinkan siswa memperoleh pengetahuan, keterampilan dan sikap. Dalam pengertian ini guru, buku teks dan lingkungan sekolah adalah media. ${ }^{9}$ Sedangkan menurut Soeparno, media merupakan perpaduan Antara hardware (perangkat keras) dan software (perangkat lunak). Dengan kata lain, media adalah hardware (perangkat keras) yang telah diisi dengan software (perangkat lunak). ${ }^{10}$

Menurut P. Ely dan Vernon S. Gerlach, media memiliki dua pengertian yaitu arti luas dan sempit. Menurut arti luas yaitu kegiatan yang dapat menciptakan kondisi, sehingga memungkinkan peserta didik dapat memperoleh pengetahuan, keterampilan dan sikap yang baru. Sedangkan menurut arti sempit media berwujud grafik, foto, alat mekanik dan elektronik yang digunakan untuk menangkap, memproses serta menyampaikan informasi. ${ }^{11}$ Dari beberapa definisi diatas, dapat disimpulkan bahwa media pembelajaran merupakan wadah atau pesan dari sumber penyalur pesan yang ingin diteruskan kepada penerima pesan tersebut.

Dari beberapa pengertian di atas, dapat dipahami bahwa yang dimaksud dengan media adalah hal-hal yang dapat membantu menyampaikan pesan dari pemberi pesan (guru) kepada penerima pesan (siswa). Dengan demikian, media berfungsi sebagai alat penyampai pesan dari pemberi kepada penerima pesan. Oleh karena

\footnotetext{
${ }^{7}$ Khalilullah, Media Pembelajaran Bahasa Arab, (Yogyakarta: Aswaja Pressindo, 2012), 23

${ }^{8}$ Asnawir dan M. Basyaruddin, Media Pembelajaran, (Jakarta: Ciputat Press, 2002), 19

${ }^{9}$ Amir Achsin, Media Pendidikan, (Ujung Pandang: IKIP, 1986), 9

${ }^{10}$ Soeparno, Media Pengajaran Bahasa, (Jakarta: Logos, 1987), 3

${ }^{11}$ Zakiah Drajat, dkk, Ilmu Pendidikan Islam, (Jakarta: Bumi Aksara, 2002), 80
} 
itu, ketepatan dan tingkat representasi sebuah media terhadap pesan yang akan disampaikan dapat turut menentukan keberhasilan proses pembelajaran.

\section{Prinsip Penggunaan Media Pembelajaran}

Prinsip pokok yang harus diperhatikan dalam penggunaan media pada setiap kegiatan belajar mengajar adalah bahwa media digunakan dan diarahkan untuk mempermudah siswa belajar dalam upaya memahami materi pelajaran. Dengan demikian, penggunaan media harus dipandang dari sudut kebutuhan siswa. Hal ini perlu ditekankan sebab sering media dipersiapkan hanya dilihat dari sudut kepentingan guru.

Media pembelajaran digunakan dalam rangka upaya peningkatan atau mempertinggi mutu proses kegiatan belajar mengajar. Oleh karena itu, harus diperhatikan prinsipprinsip penggunaannya yang antara lain:

1. Penggunaan media pengajaran hendaknya dipandang sebagai bagian yang integral dari suatu sistem pengajaran dan bukan hanya sebagai alat bantu yang berfungsi sebagai tambahan yang digunakan bila dianggap perlu dan hanya dimanfaatkan sewaktu-waktu dibutuhkan.

2. Media pengajaran hendaknya dipandang sebagai sumber belajar yang digunakan dalam usaha memecahkan masalah yang dihadapi dalam proses belajar mengajar.

3. Guru hendaknya benar-benar menguasai teknik-teknik dari suatu media pengajaran yang digunakan.

4. Guru seharusnya mempertimbangkan untung ruginya pemanfaatan suatu media pembelajaran.

5. Penggunaan media pembelajaran harus diorganisir secara sistematis bukan sembarang menggunakannya.

6. Jika sekiranya suatu pokok bahasan memerlukan lebih dari macam media, maka guru dapat memanfaatkan multimedia yang menguntungkan dan memperlancar proses belajar mengajar dan juga dapat merangsang siswa dalam belajar.

Adapun beberapa syarat umum yang harus dipenuhi dalam pemanfaatan media pembelajaran dalam proses belajar mengajar yaitu: 
1. Media pembelajaran yang digunakan harus sesuai dengan tujuan pembelajaran yang telah ditetapkan.

2. Media pembelajaran tersebut merupakan media yang dapat dilihat atau didengar.

3. Media pengajaran yang digunakan dapat merespon siswa belajar.

4. Media pengajaran juga harus sesuai dengan kondisi individu siswa.

5. Media pengajaran tersebut merupakan perantara (medium) dalam proses pembelajaran siswa.

\section{Pengertian Bahasa Arab}

Diantara pendapat mengenai sejarah asal mula bahasa Arab dan perkembangan bahasa Arab yang paling global adalah sebagai berikut:

a. Pendapat bahwa bahasa telah ada sejak zaman Adam, sehingga perintis tulisan Arab dan pola kalimat bahasa Arab adalah Adam. Pendapat ini merupakan pendapat yang paling klasik dan merupakan interpretasi secara langsung dari firman Allah :

12."وعلم ادم الأسماء كلها ثم عرضهم على الملائكة فقال أنبئوني بأسماء هؤلاء إن كنتم صادقين" Artinya: Dan dia mengajarkan kepada Adam nama-nama (benda-benda) seluruhnya, kemudian mengemukakannyab kepada para Malaikat lalu berfirman: "Sebutkanlah kepadaku nama benda-benda itu jika kamu memang benar orang-orang yang benar!”. (QS. Al-Baqarah: 31)

Dari dalil ini, mereka berpendapat bahwa nama-nama benda dan berbagai hal atau sifat didunia ini telah diajarkan oleh Allah kepada Adam dalam bahasa Arab. Bahkan pengikut pendapat ini lebih tegas menyatakan bahwa "huruf Arab telah dikuasai oleh Adam tanpa belajar dan langsung dari Allah seketika atau disebut sebagai sebuah mukjizat atau paling tidak sebagai karunia (nadzariyah al-taufiq)". ${ }^{13}$

b. Pendapat dari ahli-ahli tulisan kaligrafi Arab bahwa bahasa Arab memang ada sejak zaman Adam. Pendapat ini menyatakan bahwa bahasa Arab merupakan bahasa pertama yang diciptakan manusia dan kemudian berkembang menjadi berbagai bahasa baru, baik bahasa utamanya maupun ataupun berbagai

${ }^{12}$ Al-Qur'an, QS: Al-Baqarah ayat 31

${ }^{13}$ Fathul Mujib, Rekonstruksi Pendidikan Bahasa Arab (dari Pendekatan Konvensional ke Integratif Humanis), Yogyakarta: Pedagogia, 2010), 35 
cabang yang tumbuh darinya tersebut pada akhirnya mengalami berbagai perubahan dan perkembangan sesuai dengan peradabang manusia. Pendapat ini menggunakan bukti-bukti sejarah dan sebagainya untuk mendukung teorinya. Disebutkan bahwa dari berbagai penemuan yang ada diketahui bahwa sejak 4.000 tahun sebelum masehi, baru ada manusia yang bisa membuat abjad atau bahasa tulisan (sebelumnya dianggap belum ada bahasa tulis atau memang belum ditemukan bukti tertulisnya) yaitu oleh bangsa Sumeria ${ }^{14}$ di Mesopotamia ${ }^{15}$ yang membuatnya diatas batu, selanjutnya bangsa Mesir purba dengan sistem tulisan Hieroglif, kemudian bangsa Babilonia dan Assyria di Mesopotamia yang memakai tulisan paku atau "cuneiform"16 dan dipahatkan diatas batu, begitupun bangsa Phunisia, China, Romawi dan lain sebagainya. Mereka termasuk bangsa-bangsa yang mengawali pembangunan peradaban tinggi. Sementara itu, tulisan Arab masih tergolong muda karena lahir belakangan. Ada pendapat bahwa tulisan Arab Kufi merupakan turunan terakhir dari hieroglif setelah melewati fase tulisan phunisia, musnad dan arami hingga kemudian mencapai jenis tulisan masa sekarang.

c. Pendapat para ahli bahwa cikal bakal tulisan Arab adalah khat Nabi yang kemudian menyebar ke Hijaz dengan proses perpindahan yang diperkirakan sama dengan tahun-tahun pembuatan lima prasasti baru utama. Selain itu dari sana diperoleh gambaran pila adanya proses evolutif dari Nabti murni kemudian setelah beberapa tahap menjadi tulisan Arab yang sama dengan tulisan yang dipakai menyalin Al-Qur'an.

Menurut Al-Ghalayain, Bahasa Arab adalah kalimat-kalimat yang dipergunakan oleh orang Arab untuk mengungkapkan tujuan-tujuan (pikiran dan perasaan) mereka. ${ }^{17}$ Bahasa Arab telah memberi banyak kosakata kepada Bahasa alain dari dunia Islam, sama seperti peranan Latin kepada kebanyakan Bahasa Eropa. Semasa

\footnotetext{
${ }^{14}$ Sumeria (sekitar 3.500-2.300 tahun SM) adalah salah satu peradaban kuno di Timur Tengah, terletak disebelah selatan Mesopotamia (tenggara Irak) dari catatan terawal abad ke-4 SM sampai munculnya Babilonia pada abad ke-3 SM. Bahasa yang digunakan adalah bahasa Sumeria

${ }^{15}$ Mesopotamia terletak diantara dua sungai besar, Eufrat dan Tigris. Daerah yang kini menjadi Republik Irak itu dizaman dahulu disebut Mesopotamia yang dalam bahasa Yunani berarti "daerah diantara sungai-sungai". Nama Mesopotamia sudah digunakan oleh para penulis Yunani dan Latin kuno, seperti Polybius (abad 2 SM) dan Strabo (60 SM-20 M)

${ }^{16}$ Cuneiform adalah salah satu bentuk bahasa tulisan yang pertama kali diketahui

${ }^{17}$ Musthafa al-Ghalayain, Jami'ad-Durus al-Arabiyah jilid 1, (Beirut: Dar al-Kutub al-'Ilmiyah, 2005), 7
} 
abad pertengahan, Bahasa Arab juga merupakan alat utama budaya terutama dalam sains, matematika dan filsafat yang menyebabkan banyak Bahasa Eropa turut meminjam banyak kosakata dari Bahasa Arab.

Bahasa Arab (al-Lughah al-Arabiyyah) adalah sebuah bahasa yang terbesar dari segi jumlah penutur dalam keluarga bahasa semitik. Bahasa ini berkerabat dekat dengan Bahasa Ibrani dan Bahasa Aram. Bahasa Arab modern telah diklasifikasikan sebagai satu makrobahasa dengan 27 subbahasa dalam ISO 639-3. Bahasa-bahasa ini dituturkan diseluruh dunia Arab, sedangkan Bahasa Arab baku diketahui diseluruh dunia Islam. Bahasa Arab modern berasal dari Bahasa Arab klasik yang telah menjadi bahasa kesusastraan dan agama Islam sejak lebih kurang abad ke-6. Abjad Arab ditulis dari kanan ke kiri. ${ }^{18}$

Belajar bahasa Arab berbeda dengan belajar bahasa ibu dan prinsip dasar pembelajarannya juga berbeda, baik yang berhubungan dengan metode pembelajaran, materi maupun proses pelaksanaan pembelajarannya. Dalam pembelajaran bahasa Arab ada beberapa kemahiran yang harus dimiliki oleh seorang siswa untuk menguasai bahasa Arab dengan baik dan sempurna. Kemahiaran yang dimaksud adalah :

1. Kemahiran menyimak (Maharah Istima').

2. Kemahiran berbicara (Maharah Kalam).

3. Kemahiran membaca (Maharah Qiro'ah).

4. Kemahiran menulis (Maharah Kitabah). ${ }^{19}$

Dalam masalah penerapan media pembelajaran bahasa Arab, harus memperhatikan jiwa/psiko dari pada anak didik. Oleh karena itu, faktor inilah yang justru menjadi sasaran media pembelajaran bahasa Arab yang sangat prinsipil. Dengan tanpa memperhatikan serta memahami perkembangan jiwa anak atau tingkat daya fikir anak didik, guru bahasa Arab akan sulit diharapkan untuk menjadi sukses.

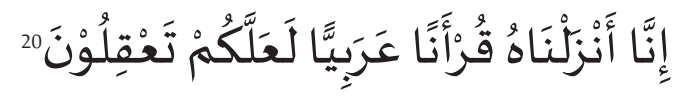

Artinya: "Sesungguhnya kami menurunkan berupa Al-Qur'an dengan berbahasa Arab, agar kamu memahaminya" (QS. Yusuf: 2)

${ }^{18}$ Ulin Nuha, Metodologi Super Efektif Pembelajaran Bahasa Arab, (Jogjakarta: DIVA Press, 2012), 32

${ }^{19}$ Ahmad Izzan, Metodologi Pembelajaran Bahasa Arab, (Bandung: Humaniora, 2009), 52

${ }^{20}$ Al-Qur'an, QS: Yusuf ayat 2 


\section{Jenis-Jenis Media Pembelajaran Bahasa Arab}

Jenis-jenis media pembelajaran jika kita tinjau dari segi penggunaan media dikaitkan dengan indera yang digunakan manusia untuk memperoleh pengetahuan, maka media diklasifikasikan menjadi tiga macam, yaitu: media audio, media visual dan media audiovisual.

\section{Media Audio}

Media pembelajaran audio adalah media yang hanya dapat didengar berupa suara dengan berbagai alat penyampai suara baik dari manusia maupun immanusia. ${ }^{21}$ Penggunaan media audio dalam pembelajaran bahasa Arab sangat penting untuk beberapa pokok pembahasan, seperti pada materi الاستماع, guru menyajikan materi dengan menggunakan media audio, seperti tape recorder dan laboratorium bahasa. Penggunaan media ini akan lebih mudah bagi siswa untuk mendengar setiap kosa kata yang diucapkan secara tepat dan untuk memudahkan kata-kata baru.

Hubungan media audio ini dengan tujuan pembelajaran pendidikan bahasa Arab sangat erat. Sebagai media yang bersifat auditif, maka media ini berhubungan erat dengan radio, alat perekam pita magnetic, piringan hitam atau mungkin laboratorium bahasa.

\section{Media Visual}

Media pembelajaran visual adalah seperangkat alat penyalur pesan dalam pembelajaran yang dapat ditangkap melalu indera penglihatan tanpa adanya suara dari alat tersebut. Dalam pembelajaran bahasa Arab, guru dapat menggunakan beberapa jenis media visual diantaranya adalah media gambar. Gambar merupakan salah satu media visual yang mampu memberikan imajinasi bagi siswa untuk menguraikan dalam bentuk kata-kata tentang peristiwa yang ditunjukkan dalam gambar tersebut. Dalam pembelajaran bahasa Arab, guru dapat menggunakan media visual dengan memberikan gambar yang melukiskan suatu peristiwa yang sedang berlangsung di sekolah, di pasar atau di terminal. Dalam penggunaan media visual ini sangat tepat digunakan pada materi insya', guru dapat mengarahkan siswa untuk mengarang dan membahasakan suatu peristiwa yang sedang terjadi sesuai dengan gambar yang disajikan. ${ }^{22}$

${ }^{21}$ M. Ramli, Media Pembelajaran Dalam Perspektif Al-Qur'an Dan Al-Hadits, Ittihad Jurnal Kopertais Wilayah XI Kalimantan Volume 13 No.23 (April 2015), 37

${ }^{22}$ Azhari, Peran Media Pendidikan Dalam Meningkatkan Kemampuan Bahasa Arab Siswa Madrasah, Jurnal Ilmiah Didaktika Agustus 2015 Vol. 16, No. 1, 54 
Pada penyampaian materi insya' penambahan kosa kata baru, guru dapat menggunakan media visual untuk memperlancar pemahaman dan memperkuat ingatan siswa. Media visual dapat pula menumbuhkan minat siswa dan dapat memberikan hubungan antara isi materi pelajaran dengan dunia nyata. Agar menjadi efektif, media visual sebaiknya memberikan bentuk yang bermakna dan dapat membuat siswa berinteraksi dengan media visual tersebut untuk meyakinkan bahwa terjadinya proses transfer informasi. Penggunaan media visual sangat ditentukan oleh indera penglihatan, dimana pesan yang disampaikan oleh media tersebut adalah dalam bentuk komunikasi visual. ${ }^{23}$

\section{Media Audio Visual}

Media Audiovisual adalah media yang dapat didengar dan dapat dilihat, melalui media audiovisual seorang guru dapat menyampaikan materi pelajaran secara lebih konkrit. Jika dibandingkan dengan penyampaian materi pelajaran yang dilakukan dengan cara lisan atau tulisan. Media audiovisual merupakan media pembelajaran yang digunakan guru untuk menyampaikan materi agar diterima siswa melalui indera pendengar dan penglihat secara terpadu. Media audiovisual mencakup siaran TV, rekaman VCD, dan pentas drama atau sandiwara. ${ }^{24}$ Media audiovisual dalam bahasa Arab dikenal juga dengan sebutan al-wasa'il al-sam'iyyah wa al-basariyyah.

\section{Peran Penting Media Pembelajaran Bahasa Arab}

Dalam proses belajar mengajar, kehadiran media pembelajaran mempunyai peran yang cukup penting. Karena dalam kegiatan tersebut kurangnya bahan yang disampaikan dapat dibantu dengan menghadirkan media sebagai perantara. Kerumitan bahan yang akan disampaikan kepada peserta didik dapat disederhanakan dengan bantuan media. Media dapat mewakili apa yang kurang mampu guru ucapkan melalui kata-kata atau kalimat tertentu. Bahkan keabstrakan bahan dapat dikonkretkan dengan kehadiran media pembelajaran.

Penggunaan media dalam pembelajaran bahasa Arab bertitik tolak dari teori yang mengatakan bahwa totalitas persentase banyaknya ilmu pengetahuan, keterampilan dan sikap yang dimiliki oleh seseorang terbanyak dan tertinggi

${ }^{23}$ Azhari, Peran Media Pendidikan Dalam Meningkatkan Kemampuan Bahasa Arab Siswa Madrasah, Jurnal Ilmiah Didaktika Agustus 2015 Vol. 16, No. 1, 45

${ }^{24}$ Jepri Nugrawiyati, Media Audio-Visual Dalam Pembelajaran Bahasa Arab, Volume 6, Nomor 1, Juni 2018; P-Issn 2338-9648, E-Issn: 2527631x, 102 
melalui indra penglihatan dan pengalaman langsung, sedangkan selebihnya melalui indra lainnya. Kegiatan belajar mengajar akan efektif dan efisien apabila dalam kegiatannya disertai dengan penggunaan media sebagai alat pembelajaran. Arif Sadiman $\mathrm{dkk}^{25}$ mengemukakan pengertian media adalah segala sesuatu yang dapat digunakan untuk menyalurkan pesan dari pengirim kepenerima sehingga dapat merangsang pikiran, perasaan, perhatian, minat siswa serta perhatian siswa dalam proses belajar mengajar

Media pembelajaran bahasa Arab yang digunakan dalam proses belajar mengajar banyak sekali, begitu juga dalam pembelajaran bahasa Arab juga bisa menggunakan media pembelajaran untuk memudahkan guru, siswa dalam belajar. Media yang dimanfaatkan dalam pembelajaran bahasa Arab antara lain: komputer, rekaman CD, gambar, grafis (peta konsep) dan sebagainya. Media-media tersebut mempunyai karakteristik tersendiri, sehingga dapat memudahkan dalam mempelajari mata pelajaran bahasa Arab yang ada di sekolah-sekolah terutama dilembaga formal.

Dalam pembelajaran bahasa, baik bahasa Arab atau bahasa Inggris, penggunaan media sangat dibutuhkan agar pembelajaran tersebut tidak membosankan dan menjadi aktivitas yang menyenangkan. Kenyataan dilapangan menunjukkan bahwa aktivitas pembelajaran bahasa Arab kurang bervariasi dari pada pembelajaran bahasa asing lainnya. Hal ini tidak hanya disebabkan adanya asumsi bahwa belajar bahasa Arab sebagai bahasa asing untuk mempergunakannya secara aktif hanya bisa dilakukan di negara Arab saja, tetapi juga penggunaan metode pembelajaran yang sudah ketinggalan dari metode pembelajaran bahasa asing lainnya. Praktek pengajaran bahasa Arab di Pesantren atau Madrasah pada umumnya masih menitikberatkan pada metode gramatika terjemah. Hal ini terbukti dengan pembelajaran yang menekankan pada keterangan kaidah-kaida tata bahasa, menerjemah bahasa Arab ke dalam bahasa pelajar tapi tidak sebaliknya, latihan secara lisan tidak diberikan dan belum menggunakan alat-alat peraga audio-visual. ${ }^{26}$

Media pembelajaran berperan penting dalam pembelajaran bahasa Arab. Media pembelajaran bukan hanya baik untuk pembelajar anak-anak, namun juga untuk pembelajar dewasa. Dalam ranah proses belajar mengajar, media pembelajaran

${ }^{25}$ Arif Sadiman dkk, Media Pendidikan, (Jakarta: PT. Raja Grafindo Persada, 2009), 23

${ }^{26}$ Tim Penyusun Buku Pedoman Bahasa Arab Direktorat Jendral Bimbingan Masyarakat Islam, Pedoman Pengajaran Bahasa Arab pada Perguruan Tinggi Agama Islam, (Jakarta: Proyek Pengembangan Sistem Pendidikan Agama Depag RI, 1978), 129 
Bahasa Arab memiliki tiga peranan penting, yaitu:

1. Peran sebagai penarik perhatian, yaitu media bersifat mengundang perhatian peserta didik, meningkatkan rasa keingintahuan siswa, serta menyampaikan informasi.

2. Peran komunikasi, yaitu berperan dalam mendorong dan membantu siswa untuk memahami pesan tertentu yang ingin disampaikan oleh guru.

3. Peran retensi, yaitu membantu pembelajar untuk mengingat konsep-konsep penting yang diperoleh selama pelajaran. ${ }^{27}$

Menurut Ahmad Salim, media pembelajaran itu sangat penting sekali mengingat beberapa unsur:

1. Menarik minat siswa

2. Meningkatkan pemahaman siswa tentang materi pelajaran

3. Memberikan data yang kuat dan terpercaya

4. Memadatkan informasi

5. Memudahkan menafsirkan data ${ }^{28}$

Dengan media ini diharapkan suasanana pembelajaran tidak membosankan dan menjadi lebih menarik sehingga bisa menumbuhkan minat siswa untuk belajar pelajaran tersebut dan yang lebih penting adalah tercapainya tujuan kegiatan belajar mengajar dan kurikulum. Hasil penelitian telah memperlihatkan bahwa media telah menunjukkan keunggulannya membantu para guru dan staf pengajar dalam menyampaikan pesan pembelajaran serta lebih cepat dan lebih mudah ditangkap oleh para siswa. Media memiliki kekuatan-kekuatan yang positif dan sinergi yang mampu merubah sikap dan tingkah laku mereka kearah perubahan yang kreatif dan dinamis. Sehubungan dengan hal itu, peran media sangat dibutuhkan dalam pembelajaran dimana dalam perkembangannya saat ini media bukan lagi dipandang sekedar alat bantu tetapi merupakan bagian yang integral dalam sistem pendidikan dan pembelajaran. ${ }^{29}$

${ }_{27}$ Abdul Wahab Rosyidi, Media Pembelajaran Bahasa Arab, (Malang: UIN Malang Press, 2009), 57

^بمحمد أحمد سالم, الوسائل التعليمية في تعليم اللغة العربية لغة أجنبية, (معهد العلوم الإسلامية والعربية

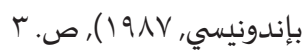
${ }^{29}$ Asnawir dan M. Basyirudin Usman, Media Pembelajaran, (Jakarta: Ciputat Pers, 2002), 105 
Namun perlu dingat bahwa peran media tidak akan terlihat bila penggunaannya tidak sejalan dengan misi dari tujuan pengajaran yang telah dirumuskan, karena itu tujuan pengajaran harus dijadikan sebagai pangkal acuan untuk menggunakan media pembelajaran.

\section{Simpulan}

Dari uraian di atas, dapat disimpulkan bahwa peranan media dalam pengajaran dan pembelajaran bahasa Arab sangat penting dalam proses belajar mengajar. Media yang sering digunakan dalam pembelajaran bahasa Arab adalah media audio, visual dan audiovisual. Untuk menggunakan jenis media tersebut dalam sebuah pembelajaran bahasa Arab, diperlukan kecakapan seorang guru, hal ini karena secanggih apapun media yang tersedia namun guru atau tenaga pengajar tidak bisa mengoperasikannya, tetap saja media tersebut tidak mampu mendukung dan menopang tercapainya sebuah keberhasilan dalam proses pembelajaran. Oleh karena itu, diperlukan teknik dan keterampilan khusus agar bisa menggunakan media-media tersebut.

Selain itu, penggunaan media harus dipandang dari sudut kebutuhan siswa pada setiap kegiatan belajar mengajar yang bertujuan untuk mempermudah siswa belajar dalam upaya memahami materi pelajaran bahasa Arab . Hal ini perlu ditekankan sebab sering media dipersiapkan hanya dilihat dari sudut kepentingan guru. Media pembelajaran digunakan dalam rangka upaya peningkatan atau mempertinggi mutu proses kegiatan belajar mengajar. Oleh karena itu, harus diperhatikan prinsipprinsip penggunaan media pembelajaran tersebut.

\section{Referensi}

Achsin, Amir. 1986. Media Pendidikan. Ujung Pandang: IKIP Asnawir dan Basyaruddin, M. 2002. Media Pembelajaran. Jakarta: Ciputat Press Azhari. Peran Media Pendidikan Dalam Meningkatkan Kemampuan Bahasa Arab Siswa Madrasah, Jurnal Ilmiah Didaktika Agustus 2015 Vol. 16, No. 1 Daryanto. 2010. Media Pembelajaran. Yogyakarta: Gava Media Drajat, Zakiah. 2002. Ilmu Pendidikan Islam. Jakarta: Bumi Aksara Izzan, Ahmad Izzan. 2009. Metodologi Pembelajaran Bahasa Arab. Bandung: Humaniora 
Khalilullah. 2012. Media Pembelajaran Bahasa Arab. Yogyakarta: Aswaja Pressindo Mujib, Fathul. 2010. Rekonstruksi Pendidikan Bahasa Arab (dari Pendekatan Konvensional ke Integratif Humanis). Yogyakarta: Pedagogia

Nawawi, Hadari. 1995. Metodologi Penelitian Bidang Sosial. Yogyakarta: Gadjahmada University Press

Nugrawiyati, Jepri. Media Audio-Visual Dalam Pembelajaran Bahasa Arab, Volume 6 Nomor 1. Juni 2018. P-Issn 2338-9648, E-Issn: 2527631

Nuha, Ulin. 2012. Metodologi Super Efektif Pembelajaran Bahasa Arab. Jogjakarta: DIVA Press

Ramli, M. Media Pembelajaran dalam Perspektif Al-Qur'an dan Al-Hadits, Ittihad Jurnal Kopertais Wilayah XI Kalimantan Volume 13 No.23 April 2015

Rohani, Ahmad. 2004. Pengelolaan Pengajaran. Jakarta: PT Rineka Cipta Rosyidi, Abdul Wahab. 2009. Media Pembelajaran Bahasa Arab. Malang: UIN Malang Press

Sadiman, Arif. 2009. Media Pendidikan. Jakarta: PT. Raja Grafindo Persada Soeparno. 1987. Media Pengajaran Bahasa. Jakarta: Logos

Tim Penyusun Buku Pedoman Bahasa Arab Direktorat Jendral Bimbingan Masyarakat Islam. 1978. Pedoman Pengajaran Bahasa Arab pada Perguruan Tinggi Agama Islam. Jakarta: Proyek Pengembangan Sistem Pendidikan Agama Depag RI

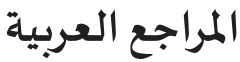

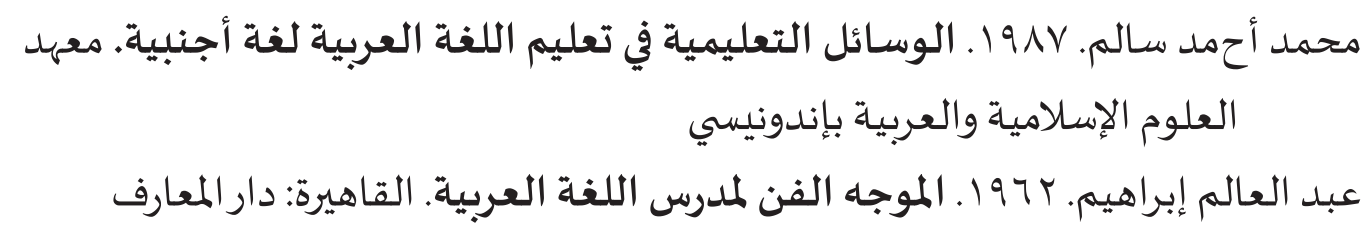

